\title{
Effect of Spartina anglica stems on near-bed hydrodynamics, sediment erodability and morphological changes on an intertidal mudflat
}

\author{
John Widdows*, Nick D. Pope, Mary D. Brinsley \\ Plymouth Marine Laboratory, Prospect Place, West Hoe, Plymouth PL1 3DH, UK
}

\begin{abstract}
Our main objective was to investigate the effect of Spartina anglica stems on hydrodynamics, sediment dynamics and their influence on seasonal morphological changes on the upper shore and salt marsh of an intertidal mudflat in the Tavy estuary (southwest England). On an intertidal transect, the greatest seasonal changes in sediment levels occurred at the seaward edge and lower part of the salt marsh, and on the lower shore mudflat, while the smallest changes occurred on the mid- and upper-shore mudflat. Flume studies demonstrated flow attenuation with increasing Spartina stem density, but this was accompanied by an increase in turbulent kinetic energy and bed shear stress $\left(\tau_{0}\right)$. The critical erosion threshold $\left(\tau_{\mathrm{e}}\right)$, however, remained relatively constant at $0.12 \mathrm{~Pa}$. Field measurements showed that $\tau_{0}$ was well below $\tau_{\mathrm{e}}$ under calm conditions. During periods of windwave activity, when daily mean wind speeds were $>8 \mathrm{~m} \mathrm{~s}^{-1}, \tau_{0}$ was greater than $\tau_{\mathrm{e}}$ in the lower salt marsh for brief periods at the beginning and end of tidal inundation. At the seaward edge of the salt marsh, $\tau_{0}$ increased to $1.0 \mathrm{~Pa}$ and $\tau_{0}$ was greater than $\tau_{\mathrm{e}}$ throughout the inundation period, causing significant sediment erosion. Wind-induced wave activity was the major driver of sediment erosion on soft muddy shores and this was enhanced by the interaction with $S$. anglica stems. The number of days per month with mean daily wind speeds $>8 \mathrm{~m} \mathrm{~s}^{-1}$ was inversely related to changes in sediment levels at the seaward edge of the salt marsh. During the summer, winds were below this threshold, and there was gradual accretion. Results are discussed in the context of climate changes involving increased storminess leading to increased erosion. We show that the $S$. anglica salt marsh should not be considered a 'bio-stabiliser' of fine muddy sediment.
\end{abstract}

KEY WORDS: Spartina anglica · Salt marsh · Intertidal · Hydrodynamics · Waves · Sediment erosion · Morphology

\section{INTRODUCTION}

As a result of predicted sea level rise and increased storminess, there is growing concern over the possibility of increased flood risk and erosion of natural coastal defences (mudflats and salt marshes) in many low-lying coastal areas. However, there is a lack of adequate understanding of the interactions between hydrodynamics (tidal currents and waves), salt marsh plants and sediment erosion/deposition, and the resultant changes in morphology over tidal and seasonal cycles.
Previous studies have shown that salt marshes attenuate tidal flows and wave activity (Pethick et al. 1990, Leonard \& Luther 1995, Shi et al. 1995, Leonard \& Reed 2002, Möller 2006). However, increased wave activity has been linked to both a reduction (Pethick 1992, van Proosdij et al. 2006) and an increase (Leonard et al. 1995, Christiansen 1998, Temmerman et al. 2004) in sedimentation. Neumeier (2005) measured the vertical velocity profile associated with a dense Spartina anglica marsh and showed an order of magnitude decline in currents from the skimming flow above the canopy to near bed flow within the canopy. Recently, a 
detailed study by Leonard \& Croft (2006) showed a $50 \%$ reduction in mean current speed and turbulent kinetic energy (TKE) within $5 \mathrm{~m}$ of the salt marsh edge (Spartina alterniflora). Similarly, Möller et al. (1999) and Möller (2006) recorded up to $50 \%$ reduction in wave height over the first 10 to $20 \mathrm{~m}$ of salt marsh vegetation. Leonard \& Croft (2006) also noted that there have been few direct measurements of turbulence within natural salt marsh canopies, and their studies confirmed the overall attenuation of tidal flow and small waves. However, these previous studies did not examine the effect of hydro-biological interactions on sediment dynamics and longer term sediment morphology changes.

Salt marsh plants, such as Spartina anglica, are generally considered to act as ecosystem engineers by modifying their environment through attenuation of waves and currents, enhanced sedimentation, and the bio-stabilisation of sediment (Brown et al. 1999, Christiansen et al. 2000, Neumeier \& Ciavola 2004). In this paper we examine whether the notion of $S$. anglica as a bio-stabiliser of sediment is entirely consistent with field observations and our understanding of interactions between hydrodynamics, Spartina stems and sediment dynamics on a fine muddy shore, in particular in a salt marsh where the majority of tidal water exchange is via the salt marsh edge rather than through a complex creek system. We are not aware of any previous study that has investigated the wider range of interactions and links between the physical processes (flow, TKE, wind-wave activity), the biota (form and density of salt marsh vegetation), sediment dynamics (effect on sediment erosion/deposition), and the resultant morphology of intertidal mudflats.

The main objectives of this study were (1) to measure the shore profile and seasonal changes in fine sediment erosion, accretion and resultant sediment morphology, particularly on the upper shore at the seaward edge of a Spartina anglica salt marsh, (2) to quantify the relationships between near-bed flows, turbulence, bed shear stress, sediment resuspension and S. anglica stem density, and (3) to relate seasonal changes in morphology to important physical-biological interactions measured in both field and flume studies.

\section{MATERIALS AND METHODS}

Study site. An intertidal mudflat was studied in the Tavy estuary, a lateral branch of the macrotidal Tamar estuary (5.5 $\mathrm{m}$ tidal range) in southwest England. The Tavy estuary is approximately $5 \mathrm{~km}$ long, running inland from the southwest to the northeast, and is likely to be affected by the dominant south-westerly winds with a fetch of $\sim 4 \mathrm{~km}$. The Blaxton site (Ord- nance Survey grid reference SX 465633) was selected on the basis of its extensive soft muddy intertidal flat (400 $\mathrm{m}$ across the tidal gradient) with a monospecific salt marsh (30 m width) of Spartina anglica (common cordgrass) on the upper shore. The seaward edge of the salt marsh, situated just above the High Water Neap Tide (HWNT) level, was characterised by a gradual ramp profile comprising soft, fine mud $(<63 \mu \mathrm{m}=$ $84.4 \pm 4.0 \% \mathrm{SE}$; median particle size $=17.4 \pm 0.2 \mu \mathrm{m})$. Due to the nature of the site (i.e. narrow width of the salt marsh in a ria system with a rising rocky substratum landward of the salt marsh) the majority of the tidal waters are exchanged via the salt marsh edge and not through a complex creek system. Morphological measurements were initiated in 2004, conducted in more detail in 2005 (monthly), and continued through 2006. During this period, there was no evidence (photographic record) of any change in stem density or position of the seaward edge of the salt marsh (i.e. no loss or progradation of salt marsh).

Measurements of sediment elevation and sediment properties. The basic shore profile was measured using a laser levelling technique from the High Water Spring Tide (HWST) level (Fig. 1). Permanent posts $(50 \times 50 \mathrm{~mm})$ were driven deep into the sediment at 3 locations on the mudflat below HWNT (lower, mid and upper) and also at 3 locations above HWNT within and seaward of the salt marsh.

On the mudflat, the sediment levels around the lower, mid and upper posts were determined using a $2 \mathrm{~m}$ aluminium beam placed at one end on the fixed post and at the other on a pole that was temporarily pushed into the mud until the beam was horizontal (checked with a $0.5 \mathrm{~m}$ spirit level). The distance between the horizontal beam and the sediment was measured to the nearest $\mathrm{mm}$ at 1.5, 1.75 and $2 \mathrm{~m}$ from the

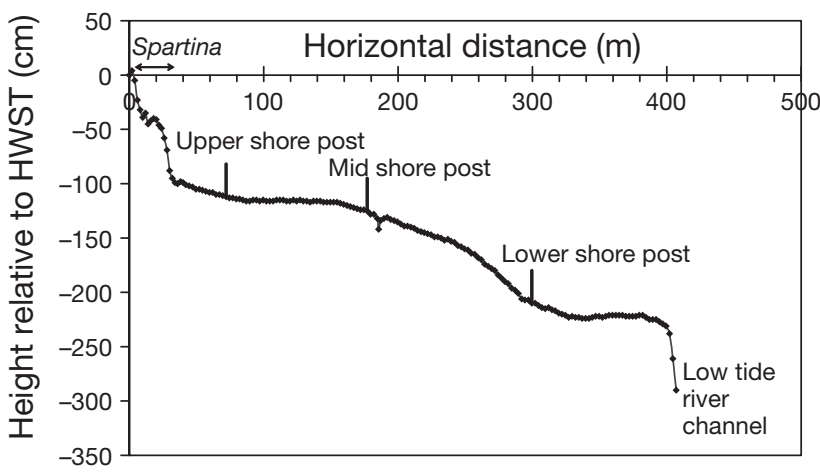

Fig. 1. Shore-normal profile of Blaxton intertidal mudflat (Tavy estuary, southwest UK) with surface elevation relative to high water spring tide (HWST) level (March 2004). The profile illustrates the location of a Spartina anglica salt marsh, which grows $\sim 30 \mathrm{~m}$ seaward from HWST level, and three permanent posts for measuring monthly changes in sediment level on the upper, mid and lower shore 
post in north, east, south and west bearings from the post ( $\mathrm{n}=12$ readings). This prevented any disturbance of sediment in the vicinity of the post and avoided any area of scouring by tidal currents and waves around the post (a feature of the lower shore post). The sediment levels relative to the fixed posts were measured on 6 occasions during 2004 (from January to August), and then at monthly intervals throughout 2005, and in winter, spring and summer 2006.

Sediment levels within the lower salt marsh and seaward of the salt marsh were measured (at $0.25 \mathrm{~m}$ intervals) along a $12 \mathrm{~m}$ shore-normal transect to provide a more detailed profile at this location. The initial detailed profile of the lower salt marsh at the end of winter (March 2004) showed a distinct change in sediment heights, with a deep depression $(80 \mathrm{~mm})$ at the edge of the salt marsh ( 6.5 $\mathrm{m}$ horizontal distance in Fig. 2) and/or a marked shoulder of deposited sediment in front of the salt marsh ( 7 to $8 \mathrm{~m}$ in Fig. 2). A photograph of the seaward edge of the salt marsh with the depression and shoulder is shown in Fig. 3. This morphological feature ran along the front edge of the salt marsh. We hypothesised that there were two possible explanations for the profile: (1) the shoulder resulted from enhanced sedimentation in front of the salt marsh and the natural profile was ca. $70 \mathrm{~mm}$ lower (dashed line in Fig. 2), and/or (2) the depression is caused by the increased turbulence and erosion induced by the Spartina stems at the seaward edge. Subsequent field and flume studies were designed to examine the dynamic nature of this profile and possible causal processes.
Spartina anglica stem density was measured at $2 \mathrm{~m}$ intervals along the shore-normal transect using a $20 \times$ $20 \mathrm{~cm}$ quadrat $(\mathrm{n}=5)$. The volume of root/rhizome below the sediment surface was determined by taking 3 cores containing cordgrass $(10 \mathrm{~cm}$ diameter by $15 \mathrm{~cm}$ depth) both at the edge of the salt marsh and $3 \mathrm{~m}$ seaward in November 2005. The cores were sectioned into $0-5,5-10$ and $10-15 \mathrm{~cm}$ depths, the sediment was washed off the roots/rhizomes over a coarse sieve, and the displacement volumes of stems, roots and rhizomes were then estimated and expressed relative to the total volume of the core.

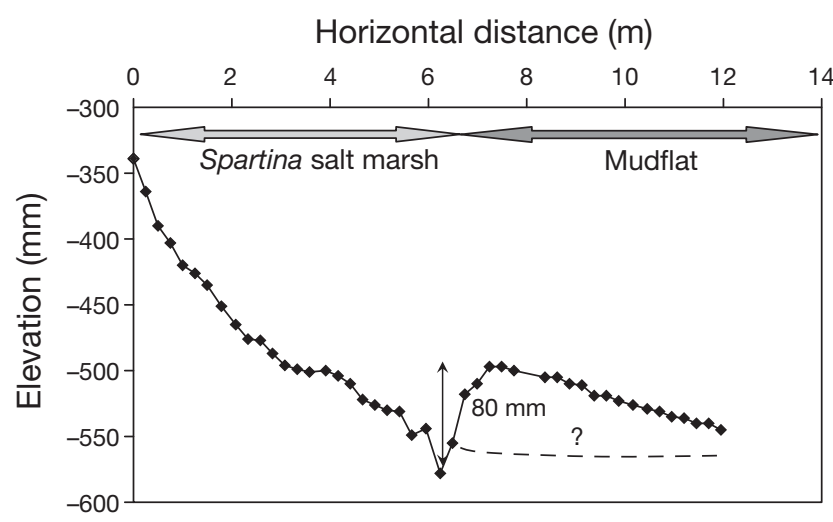

Fig. 2. Detailed profile of lower salt marsh $(6.5 \mathrm{~m})$ and upper mudflat $(5.5 \mathrm{~m})$ illustrating the depression and shoulder at the front edge of the Spartina anglica salt marsh (March 2004). Bed elevation is relative to a fixed post in the upper salt marsh. Dashed line: hypothetical 'natural' profile
Fig. 3. Photograph of the depression and shoulder at the seaward edge of the Spartina anglica salt marsh at Blaxton in January 2005. Arrowhead denotes location of Sontek ADV (Acoustic Doppler Velocimeter) for measuring hydrodynamics at the seaward edge of the salt marsh. $S$. anglica height $\approx 45 \mathrm{~cm}$

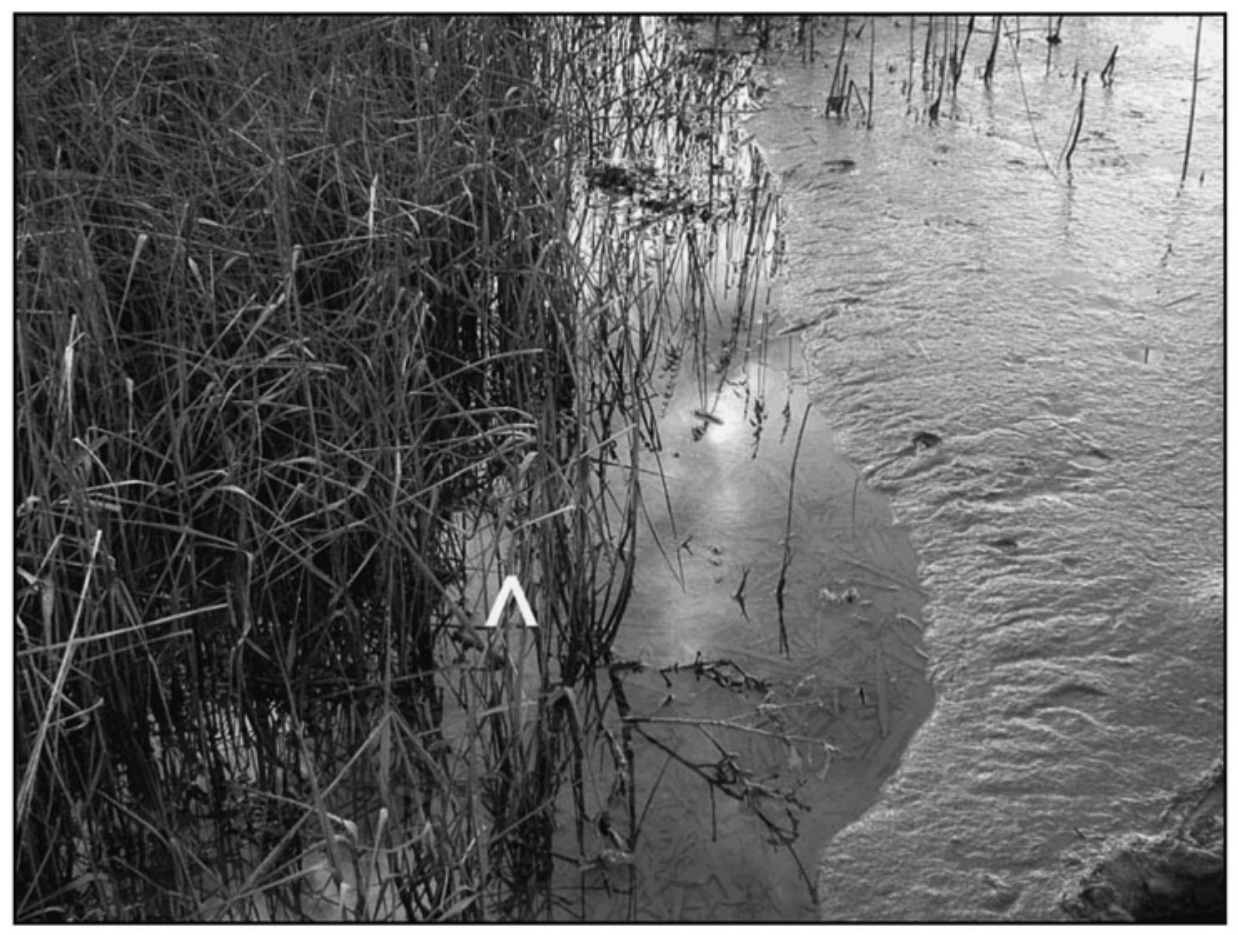


Background information on aspects of the biological properties of the Blaxton mudflat was provided by other parallel field studies. These measurements were not considered essential to this investigation because these other studies show that intertidal mudflats within the middle and lower Tamar/Tavy estuary have relatively consistent critical erosion thresholds $(\sim 0.1 \mathrm{~Pa}$; Bale et al. 2007, Widdows et al. 2007, Pilditch et al. 2008). This largely reflects the overall balance between bio-stabilisers, such as microphytobenthos $($ mean \pm SE ranging from $12.2 \pm 0.6$ to $27.6 \pm 0.9 \mu \mathrm{g} \mathrm{chl}$ $\mathrm{a} \mathrm{g}^{-1}$ wet wt), and macrofauna acting as bio-destabilisers (predominantly Hydrobia ulvae, $\sim 1600$ ind. $\mathrm{m}^{-2}$; and Nereis diversicolor, 854 ind. $\mathrm{m}^{-2}$ ), without any marked temporal or spatial changes in sediment stability. This is in contrast to other studies at intertidal sites in estuaries on the North Sea coast, such as the Humber (Widdows et al. 2000b), Westerschelde (Widdows et al. 2004) and Essex estuaries (Widdows et al. 2006), where the abundance of these key biota can undergo more marked variability.

Measurements of hydrodynamics. Spring tidal cycles of near-bed $(\mathrm{z}=0.05 \mathrm{~m}$ above the bed) current velocities, TKE, water depth and suspended sediment concentrations were measured at three locations on the upper shore. Measurements were made (1) on the unvegetated mudflat at the same elevation as the salt marsh (6 m southwest of the salt marsh), (2) at the seaward edge of the Spartina anglica marsh (Fig. 3), and (3) within the salt marsh (2 $\mathrm{m}$ from the seaward edge), over periods of calm and windy weather in March and April 2005. Bed shear stress $\left(\tau_{0}\right)$ was calculated from TKE measured within the benthic boundary layer (where $\tau_{0}=0.19 \times \mathrm{TKE}$; Stapleton \& Huntley 1995, Pope et al. 2006). Due to equipment limitation, it was not possible to make simultaneous measurements at all 3 sites. Instruments included a Sontek micro Acoustic Doppler Velocimeter (ADV Field) with an optical back-scatter sensor (OBS-3) coupled to a Hydra System (power supply and data logging), the Plymouth Marine Laboratory's (PML) mini-rig, incorporating an $x-y$ electromagnetic (EM) current meter (5.5 cm spherical head, Valeport 800), an OBS-1, and a depth pressure sensor (Druck PDCR 940 0-7 Bar absolute) coupled to a microprocessor controller-logger and power supply. Both the Sontek ADV/Hydra and PML's mini-rig were programmed to record for $3 \mathrm{~min}$ every $15 \mathrm{~min}$. The OBS sensors were calibrated against water samples with resuspended sediment obtained from flume experiments run with sediment collected from the upper shore at Blaxton. These were filtered onto pre-weighed glass fibre filters (GFC), washed with distilled water, dried at $90^{\circ} \mathrm{C}$ and re-weighed together with blank filters.
Flume studies of hydrodynamics, sediment erosion and deposition. A detailed description of the annular flume and the operating procedures is provided by Widdows et al. (1998, 2000a). In short, the flume represents a smaller, modified version of the design described by Fukuda \& Lick (1980). The annular flume was constructed of acrylic material with a $64 \mathrm{~cm}$ (outer) and $44 \mathrm{~cm}$ (inner) diameter, resulting in a $10 \mathrm{~cm}$ channel width with a total bed area of $0.17 \mathrm{~m}^{2}$, a maximum water depth of $38 \mathrm{~cm}$, and a maximum volume of $60 \mathrm{l}$. The flume was controlled and logged by a portable computer using LabView software. Water flow, ranging from 0.05 to $0.40 \mathrm{~m} \mathrm{~s}^{-1}$, was generated by four paddles $(9 \times 6.5 \mathrm{~cm})$ attached to a rotating cylinder driven by a motor and gearbox with built-in rpm counter. Changes in suspended sediment concentration (SSC) were monitored (every $15 \mathrm{~s}$ ) with an optical backscatter sensor (OBS-3M, D \& A Instruments) flushmounted in the outer wall. The OBS output (volts) was calibrated against water samples taken for gravimetric analysis and calibration curves were produced for each experiment. This allowed the calculation of SSC $\left(\mathrm{mg} \mathrm{l}^{-1}\right)$, and sediment erodability was quantified in terms of critical erosion velocity $\left(U_{\text {crit }}, \mathrm{m} \mathrm{s}^{-1}\right)$, critical erosion bed shear stress $\left(\tau_{\mathrm{e}}, \mathrm{Pa}\right)$, and mass of sediment eroded $\left(\mathrm{ME}, \mathrm{g} \mathrm{m}^{-2}\right)$. $U_{\text {crit }}$ is defined as the depth-averaged current velocity required to erode $10 \mathrm{~g} \mathrm{~m}^{-2}$ and was estimated from the linear relationship between log ME and $\log \bar{U}$ (Widdows et al. 1998, Roast et al. 2004). This reflects the erosion of bed sediment (type Ib erosion) without including the resuspension of small amounts of recently deposited flocs and aggregates. $\tau_{\text {crit }}$ was calculated from the linear relationship between ME and $\log \tau_{0}$ above the inflexion in the erosion curve, and the regression equation was then used to extrapolate back to the $x$ axis.

Sediments were collected from the mudflat and the salt marsh at Blaxton on the Tavy estuary. Flume experiments examined the effect of both artificially planted Spartina anglica stems at different densities (even distribution from 0 to 1650 stems $\mathrm{m}^{-2}$ ) and natural $S$. anglica stems (clumped distribution) on nearbed hydrodynamics and sediment erodability. Bare sediments and sediments with cordgrass stem and root/ rhizome systems were cored from the sampling site to a depth of $7 \mathrm{~cm}$ using stainless-steel quadrant box cores (4 cores forming an annulus) designed to fit precisely into the annular flumes. The quadrant box cores were pushed into the sediment and dug out, base plates were inserted and the cores lifted for transportation to two identical flumes located at PML. The quadrant box cores were carefully inserted into the flumes and the stainless-steel boxes were then removed leaving the sediment and base plates in the flumes. The four sediment blocks were then carefully pushed to- 
gether to fill any small gaps, and the final space was filled with a slice of sediment from an additional core. Such coring methods enable the collection of relatively undisturbed sediments with surface features, stratification and natural benthic community. Previous studies have demonstrated that there are no significant differences in sediment erodability between the in situ and laboratory-based flume measurements using quadrant box cored sediment (Widdows et al. 2000a, 2007).

After inserting the sediment cores into the flume, a sheet of 'bubble wrap' plastic packaging the size and shape of the annulus was carefully placed on the sediment surface and seawater was gently pumped onto the sheet, which then gradually floated off without disturbing the sediment surface. The flumes were then filled with 461 of water $(27 \mathrm{~cm}$ depth) and gently aerated to maintain fully oxygenated water prior to erosion experiments. Current speed was increased stepwise in $5 \mathrm{~cm} \mathrm{~s}^{-1}$ increments from 5 to $40 \mathrm{~cm} \mathrm{~s}^{-1}$, each for a period of $20 \mathrm{~min}$. A Sontek micro-ADV was used to measure vertical profiles in current speed and TKE, from $0.5 \mathrm{~cm}$ above the bed and then at $1 \mathrm{~cm}$ intervals from 1 to $9 \mathrm{~cm}$ (Pope et al. 2006). Bed shear stress in the flume studies was calculated from TKE measured within the compressed boundary layer (i.e. at $\mathrm{z}=$ $0.5 \mathrm{~cm})$. At $>2 \mathrm{~cm}$ above the bed, currents and TKE are relatively independent of depth and therefore there is little difference between depth-averaged current speed $(\bar{U})$ in the flume and $U$ at $\mathrm{z}=5 \mathrm{~cm}$. Consequently there is good agreement in the relationship between $U$ and $\tau_{0}$ in both the flume and field (Pope et al. 2006). The relationship between mean current speed $(U)$ and bed shear stress ( $\tau_{0}$, in Pa) in both PML's annular flume and in the field over relatively smooth intertidal mudflats (i.e. shallow water) is described by the following equation:

Bed shear stress $=4.7608 U^{3}-1.2607 U^{2}+0.4264 U$ where $U$ is speed in $\mathrm{m} \mathrm{s}^{-1}$ at $5 \mathrm{~cm}$ above the bed $\left(\mathrm{r}^{2}=\right.$ 0.99).

\section{RESULTS}

\section{Shore profile of sediment height and Spartina anglica density}

The shore-normal profile of the Blaxton intertidal mudflat, with the location of the fixed upper, mid and lower shore posts, is illustrated in Fig. 1. A more detailed initial profile (March 2004) of the lower $6.5 \mathrm{~m}$ of salt marsh and the upper $5.5 \mathrm{~m}$ of mudflat is presented in Fig. 2, showing the marked depression and/or shoulder at the seaward edge. A photograph of the salt marsh front edge shows the depression and shoulder in January 2005 (Fig. 3). Mean ( \pm SE) Spartina anglica stem density increased from $420 \pm 81$ stems $\mathrm{m}^{-2}$ at the seaward edge, to $610 \pm 59$ stems $\mathrm{m}^{-2}$ at 2 to $8 \mathrm{~m}$ from the marsh edge, to between $950 \pm 63$ and $1100 \pm 42$ stems $\mathrm{m}^{-2}$ in the inner salt marsh ( $>10 \mathrm{~m}$ from edge).

Effect of Spartina anglica on near-bed hydrodynamics and sediment erodability: flume studies

Fig. 4 illustrates the depth-averaged current velocity at different flume speeds as a function of stem density. There was a marked reduction in flow with increasing stem density, particularly between 0 (bare mud) and 400 stems $^{-2}(3.5 \times$ reduction at high flows and $5.5 \times$ reduction at low flows), followed by more modest reductions with further increases in stem density ( $>400$ stems $\mathrm{m}^{-2}$ ). Although cordgrass stems caused a reduction in near bed flows, they induced a marked increase in TKE and thus bed shear stress $\left(\tau_{0}\right)$, particularly at densities of $>100$ planted stems $\mathrm{m}^{-2}$ (Fig. 5). For a given flow speed, $\tau_{0}$ increased dramatically with increasing stem density. For example, at $0.15 \mathrm{~m} \mathrm{~s}^{-1}$, a stem density of $800 \mathrm{~m}^{-2}$ enhanced $\tau_{0} 7$-fold above that recorded for bare sediment. The relationship between $\tau_{0}$ and current speed up to $0.1 \mathrm{~m} \mathrm{~s}^{-1}$ for artificially planted stems (even distribution) was consistent with natural clumped stems suggesting that the planted stems adequately represented the natural condition. At higher current speeds, the relationship for natural clumped stems at 659 stems $\mathrm{m}^{-2}$ was equivalent to 800 planted stems $\mathrm{m}^{-2}$. The slightly higher density-dependent $\tau_{0}$ associated with natural clumped stems probably reflected the more complex structure and the rougher natural bed (with some leaf litter) compared to the smooth mud used for the planted stems.

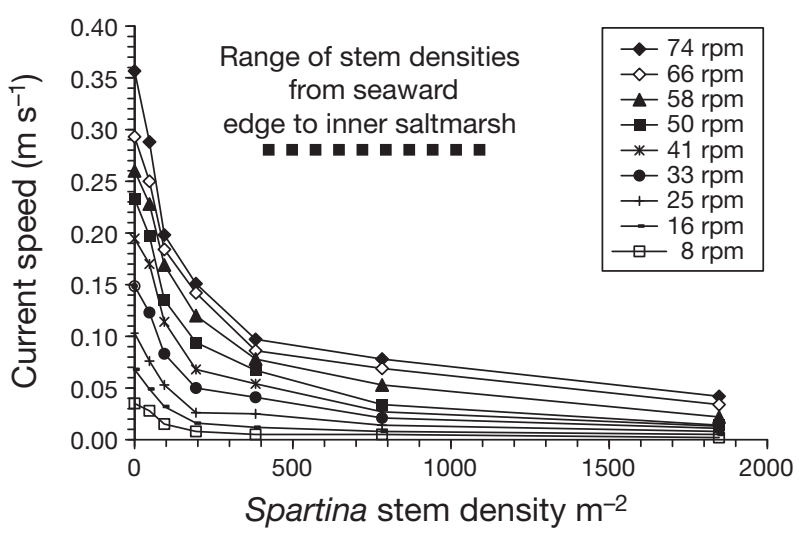

Fig. 4. Relationship between depth-averaged current velocity $\left(\mathrm{m} \mathrm{s}^{-1}\right)$ and Spartina anglica density (stems $\left.\mathrm{m}^{-2}\right)$ at different flume rotation speeds (rpm) 


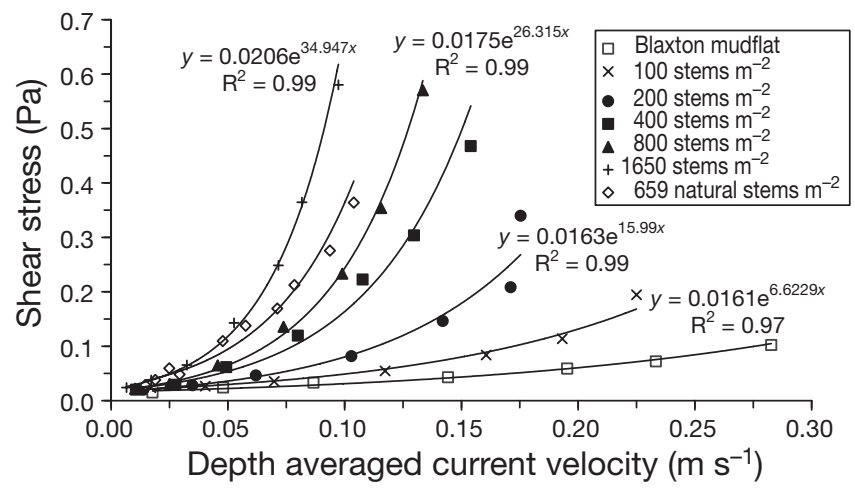

Fig. 5. Relationship between bed shear stress (Pa) and depthaveraged current velocity for different Spartina anglica densities from 100 to $1650 \mathrm{stems} \mathrm{m}^{-2}$. Flume studies involved artificially planted stems in cored mud from the upper shore mudflat, as well as sediment with natural clumped $S$. anglica stems cored from the Blaxton salt marsh. For reasons of clarity, exponential equations and $\mathrm{R}^{2}$ values accompany every second fitted curve

There was a $>2$-fold reduction in critical erosion velocity $\left(U_{\text {crit }}\right)$ with increasing stem density. $U_{\text {crit }}$ was reduced from $0.19 \mathrm{~m} \mathrm{~s}^{-1}$ for bare sediment to $0.11 \mathrm{~m} \mathrm{~s}^{-2}$ for a Spartina anglica density of 200 stems $\mathrm{m}^{-2}$, $0.09 \mathrm{~m} \mathrm{~s}^{-1}$ for densities of 400 to 812 stems $\mathrm{m}^{-2}$, and $0.075 \mathrm{~m} \mathrm{~s}^{-1}$ at 1645 stems $\mathrm{m}^{-2}$. However, when erosion threshold is expressed in terms of critical bed shear stress for erosion $\left(\tau_{\mathrm{e}}\right)$, there is little difference between the conditions (Fig. 6, $\tau_{\mathrm{e}}=0.10$ to $0.12 \mathrm{~Pa}$ and densities between 200 and 800 stems $\mathrm{m}^{-2}$ ). This is consistent with theory and indicates that it is the force or shear stress applied to the bed that determines the onset of sediment erosion.

\section{Field measurement of hydrodynamics and SSC in relation to Spartina density and wind speed}

Mean current speed $(U)$, bed shear stress $\left(\tau_{0}\right)$ and water depth were measured inside the salt marsh, at the seaward edge of the salt marsh, and on the bare mudflat at 15 min intervals during spring tides with maximum water depths of $\sim 1 \mathrm{~m}$. Measurements were made at the 3 locations during calm weather (mean wind speeds $<6 \mathrm{~m} \mathrm{~s}^{-1}$ during inundation period) and compared with windy conditions (with mean wind speeds $>8 \mathrm{~m} \mathrm{~s}^{-1}$ and maximum wind speeds of 17 to $20 \mathrm{~m} \mathrm{~s}^{-1}$ ).

Fig. 7 illustrates the low $U$ and $\tau_{0}$ values occurring $2 \mathrm{~m}$ inside the salt marsh during the $4.5 \mathrm{~h}$ inundation period on a calm day. The maximum $\tau_{0}$ was an order of magnitude below the erosion threshold $\left(\tau_{\mathrm{e}}=0.12 \mathrm{~Pa}\right)$ under these conditions. During windy conditions, however, there was a dramatic increase in the $\tau_{0}$ so that it was above the critical erosion threshold $\left(\tau_{\mathrm{e}}\right)$ for $\sim 40 \%$ of the inundation period (Fig.7). This was when the water

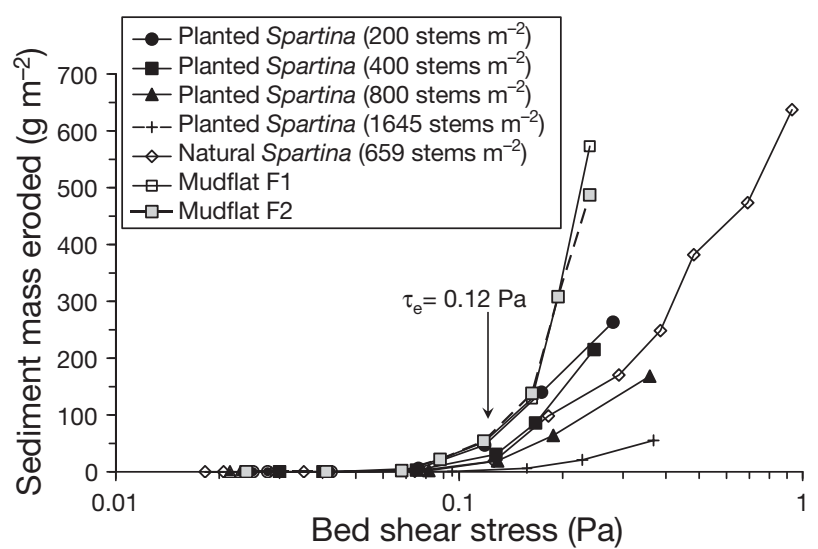

Fig. 6. Relationship between sediment mass eroded $\left(\mathrm{g} \mathrm{m}^{-2}\right)$ and $\log$ bed shear stress (Pa), showing similar critical erosion thresholds ( $\tau_{\mathrm{e}}: 0.10$ to $\left.0.12 \mathrm{~Pa}\right)$ for bare mud (F1 and F2) and different Spartina anglica stem densities (artificially planted and natural)

depth was $<0.5 \mathrm{~m}$ during the initial 15 to $30 \mathrm{~min}$ of the flood tide, but to a greater extent during last $60 \mathrm{~min}$ of the ebb tide when $\tau_{0}$ reached a maximum of $0.50 \mathrm{~Pa}$.

In contrast, at the seaward edge of the salt marsh (Fig. 8), even under relatively calm conditions, the $\tau_{0}$ was above the $\tau_{\mathrm{e}}$ for 15 to $30 \mathrm{~min}$ at the beginning of flood tide and at the end of ebb tide. During windy conditions, there was a significant increase in $U$ to $0.087 \mathrm{~m} \mathrm{~s}^{-1}$ and $>10$-fold increase in $\tau_{0}$ to $1.0 \mathrm{~Pa}$, such that $\tau_{0}>\tau_{\mathrm{e}}$ throughout the whole tidal cycle. The maximum $U$ and $\tau_{0}$ values occurred when the water depth was $<0.3 \mathrm{~m}$, enabling energy associated with short period waves $\left(T_{p}=1 \mathrm{~s}\right)$ with significant wave heights

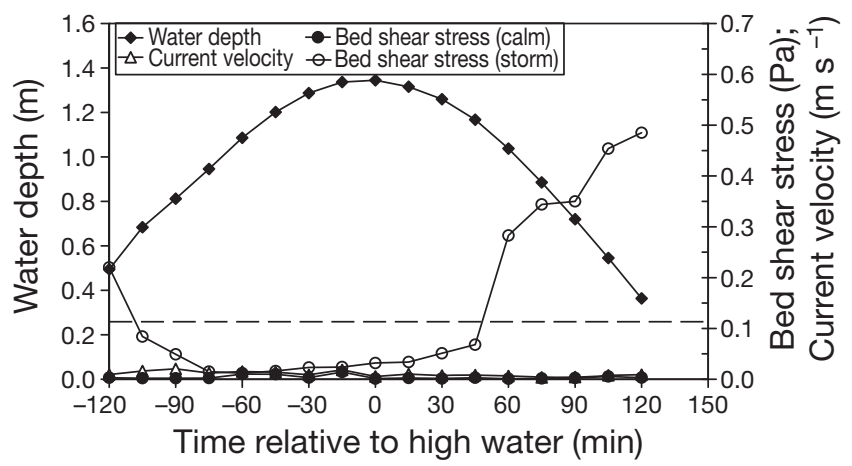

Fig. 7. Measurement of bed shear stress $(\mathrm{Pa})$ and mean current speed $\left(\mathrm{m} \mathrm{s}^{-1}\right)$ at a site $2 \mathrm{~m}$ into the salt marsh from the seaward edge during a $4 \mathrm{~h}$ inundation period on a calm day (9 April 2005: mean wind speed $=4.3 \mathrm{~m} \mathrm{~s}^{-1}$, suspended sediment concentration $[\mathrm{SSC}]=27-68 \mathrm{mg} \mathrm{l}^{-1}, U=0.004-0.015 \mathrm{~m}$ $\mathrm{s}^{-1}, \tau_{0}=0.001-0.01[\mathrm{~Pa}]$, significant wave height $\left[\mathrm{H}_{\mathrm{s}}\right]=8.6 \pm$ $0.6[\mathrm{SE}] \mathrm{cm}$, wave period $\left[\mathrm{T}_{\mathrm{p}}\right]=1 \pm 0.1[\mathrm{SE}] \mathrm{s}$ ), and a windy day (20 March 2004: wind speeds $=8-17 \mathrm{~m} \mathrm{~s}^{-1}, \mathrm{SSC}=$ $37-742 \mathrm{mg} \mathrm{l}^{-1}, U=0.002-0.017 \mathrm{~m} \mathrm{~s}^{-1}, \tau_{0}=0.01-0.49 \mathrm{~Pa}_{1} \mathrm{H}_{\mathrm{s}}=$ $\left.13.1 \pm 0.7 \mathrm{~cm}, \mathrm{~T}_{\mathrm{p}}=1 \pm 0.1 \mathrm{~s}\right)$. Dashed line: critical erosion threshold $\left(\tau_{\mathrm{e}}\right)$ 


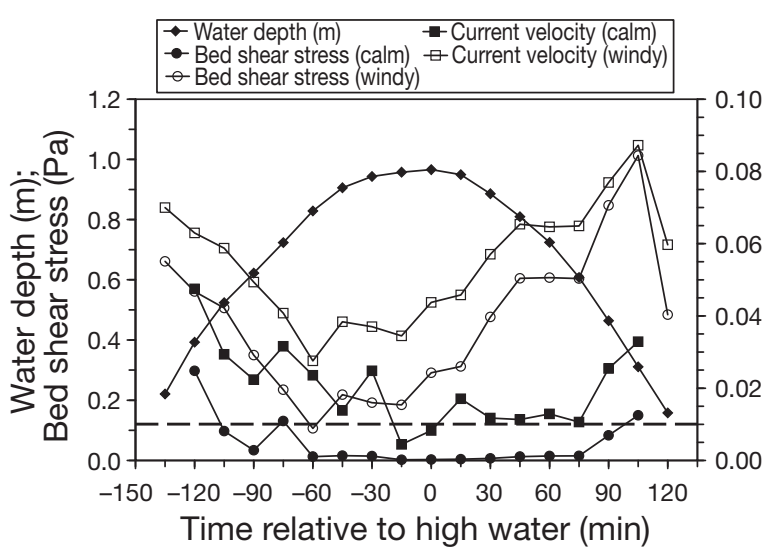

Fig. 8. Measurement of bed shear stress $(\mathrm{Pa})$ and mean current velocity $\left(\mathrm{m} \mathrm{s}^{-1}\right)$ at the seaward edge of the salt marsh (stem height $\sim 0.5 \mathrm{~m}$ ) during a $4 \mathrm{~h}$ inundation period on a relatively calm day ( 7 April 2005: wind speeds $=4-8 \mathrm{~m} \mathrm{~s}^{-1}, \mathrm{SSC}=$ 31-174 $\left.\mathrm{mg} \mathrm{l}^{-1}, \mathrm{H}_{\mathrm{s}}=10.4 \pm 0.5[\mathrm{SE}] \mathrm{cm} ; \mathrm{T}_{\mathrm{p}}=1.0 \pm 0.1[\mathrm{SE}] \mathrm{s}\right)$ and on a windy day (6 April 2005: wind speeds $=8-20 \mathrm{~m} \mathrm{~s}^{-1}$, $\left.\mathrm{SSC}=109-999 \mathrm{mg} \mathrm{l}^{-1}, \mathrm{H}_{\mathrm{s}}=15.5 \pm 0.6 \mathrm{~cm}, \mathrm{~T}_{\mathrm{p}}=1 \pm 0.1 \mathrm{~s}\right)$. Dashed line: critical erosion threshold $\left(\tau_{\mathrm{e}}\right)$

$\left(\mathrm{H}_{\mathrm{s}}\right)$ of $15.5 \mathrm{~cm}$ to penetrate to the bed. The lowest $U$ and $\tau_{0}$ values occurred when water levels were greater than the height of the Spartina stems, presumably allowing skimming flow above the canopy (though not measured in this study). There was a significant exponential relationship between bed shear stress and mean current velocity $\left(\mathrm{p}<0.001, \mathrm{r}^{2}=0.96\right)$ during the period of increased wind speed. As a result of the significant increase in $\tau_{0}$ (i.e. $\tau_{0}>\tau_{\mathrm{e}}$ ), there was considerable sediment resuspension, with up to $1 \mathrm{~g} \mathrm{l}^{-1}$ in the shallow water $(0.1$ to $1 \mathrm{~m})$ during tidal inundation of the upper shore. There was a significant correlation between $\tau_{0}$ and SSC $\left(\mathrm{p}<0.001, \mathrm{r}^{2}=0.58\right.$, and $\mathrm{p}<0.001$, $\mathrm{r}^{2}=0.90$ on 6 and 7 April, 2005, respectively).

Fig. 9 provides a synthesis of the field data and illustrates changes in the relationship between bed shear stress and current velocity as a function of intertidal location (mudflat, salt marsh or salt marsh edge) and with and without wind-induced wave activity. At the Blaxton site under calm conditions (wind speeds $<6 \mathrm{~m}$ $\mathrm{s}^{-1}$ ), intertidal mud (i.e. smooth surface) induced a low bed shear stress $\left(\tau_{0}\right)$ for a given current velocity $(U)$. This was consistent with the relationship previously recorded for smooth mud on the mid shore by Pope et al. (2006), where $\tau_{0}$ begins to deviate from a near-linear relationship only at $U$ values $>0.20 \mathrm{~m} \mathrm{~s}^{-1}$. On the Blaxton mudflat under calm conditions, $\tau_{0}$ was greater than $\tau_{\mathrm{e}}$ only at current speeds $>0.25 \mathrm{~m} \mathrm{~s}^{-1}$. However, under conditions of wind-induced wave activity, bed shear stress increased markedly and was above $\tau_{\mathrm{e}}$ at mean current velocities $>0.06 \mathrm{~m} \mathrm{~s}^{-1}$ (Fig. 9). At the salt marsh edge under calm conditions, the near-bed flows were dramatically reduced to $<0.04 \mathrm{~m} \mathrm{~s}^{-1}$ with $\tau_{0}<0.15 \mathrm{~Pa}$.

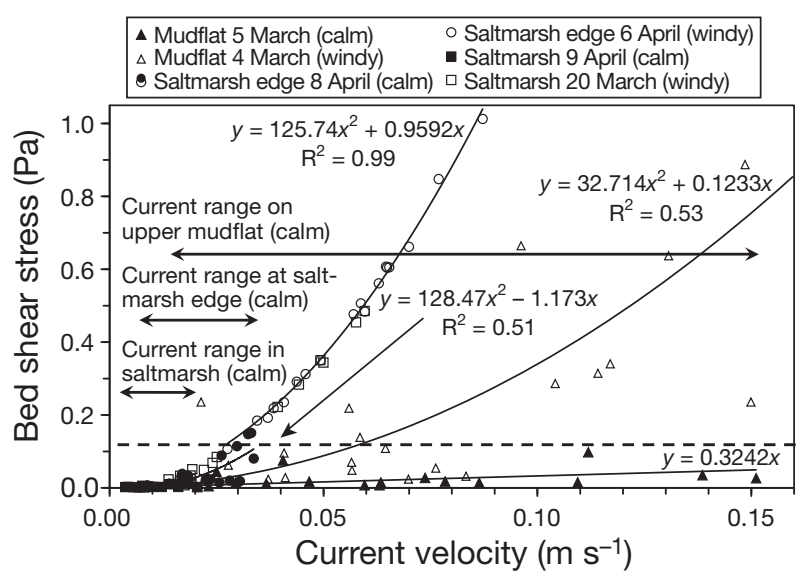

Fig. 9. Relationship between bed shear stress (Pa) and mean current velocity $\left(\mathrm{m} \mathrm{s}^{-1}\right)$ on the mudflat $(\mathbf{\Lambda})$, at the edge of the salt marsh $(\bullet)$, and $2 \mathrm{~m}$ inside the Spartina anglica salt marsh (घ) during spring tides (i.e. $1 \mathrm{~m}$ water depth) and under calm conditions $(\boldsymbol{\Lambda}, \bullet, \square)$ and windy conditions $(\Delta, \bigcirc, \square)$. Prevailing wind and wave conditions coinciding with hydrodynamic measurements at seaward edge and $2 \mathrm{~m}$ within salt marsh are presented in legends of Figs. 7 \& 8. Mudflat measurements on a relatively calm day (5 March 2004: wind speeds $=2-6 \mathrm{~m} \mathrm{~s}^{-1}$, $\mathrm{SSC}=20-70 \mathrm{mg} \mathrm{l}^{-1}, U=0.01-0.15 \mathrm{~m} \mathrm{~s}^{-1}, \mathrm{H}_{\mathrm{s}}=9.5 \pm 0.36$ [SE] $\mathrm{cm}, \mathrm{T}_{\mathrm{p}}=1.04 \pm 0.047[\mathrm{SE}] \mathrm{s}$ ) and on a windy day (4 March 2005: wind speeds $=8-13 \mathrm{~m} \mathrm{~s}^{-1}, \mathrm{SSC}=42-428 \mathrm{mg} \mathrm{l}^{-1}, \mathrm{H}_{\mathrm{s}}=$ $\left.11.7 \pm 1.01 \mathrm{~cm}, \mathrm{~T}_{\mathrm{p}}=1.43 \pm 0.1 \mathrm{~s}\right)$. Dashed line: critical erosion threshold $\left(\tau_{\mathrm{e}}\right)$ established in flume studies

But in response to wind-wave activity, the flows and bed shear stress were increased to $0.087 \mathrm{~m} \mathrm{~s}^{-1}$ and $1.01 \mathrm{~Pa}$, respectively, with $\tau_{0}>\tau_{\mathrm{e}}$ at current speeds $>0.03 \mathrm{~m} \mathrm{~s}^{-1}$. In comparison to the mudflat, there was marked attenuation of near-bed flow accompanied by increased turbulence, resulting in an 8-fold increase in $\tau_{0}$ within the salt marsh and at the seaward edge of the salt marsh. The relationships between $\tau_{0}$ and $U$ were similar for the inner salt marsh and the seaward edge of the salt marsh (Fig. 9). However, under windy conditions, there was a $50 \%$ reduction in the maximum $\tau_{0}$ within $2 \mathrm{~m}$ of the salt marsh edge, and $\tau_{0}$ was therefore only above $\tau_{\mathrm{e}}$ for $\sim 40 \%$ of the inundation period compared to $100 \%$ at the seaward edge. There was also agreement between the flume and field (calm) data for the relationship between $\tau_{0}$ and $U$. The flume data for natural and planted stems at the higher stem densities (Fig. 5) fall within the scatter of points measured in the field (Fig. 9), which includes some small wave activity, even on relatively calm days.

\section{Seasonal and spatial changes in sediment levels and intertidal shore profile}

During 2005, monthly changes in sediment levels were monitored at $0.25 \mathrm{~m}$ intervals between the lower 
$6.5 \mathrm{~m}$ of the Spartina anglica salt marsh and the $5.5 \mathrm{~m}$ of upper shore mudflat seaward of the marsh, as well as at the upper, mid and lower posts on the intertidal mudflat. For reasons of clarity, only a summary of the quarterly readings for the salt marsh and upper mudflat are illustrated in Fig. 10 (monthly data shown in Fig. 11). The plots show the marked spatial and temporal changes in sediment levels at the seaward edge of the salt marsh over the seasonal cycle. During autumn and winter, there was significant sediment erosion from the lower part of the salt marsh, with a total annual change (TAC) of $53 \mathrm{~mm}$ between 1 and $2 \mathrm{~m}$ landward from the seaward edge, and the development of a pronounced depression at the seaward edge of the salt marsh $(\mathrm{TAC}=88 \mathrm{~mm})$. This was accompanied by accretion on the mudflat seaward of the salt marsh $(\mathrm{TAC}=31 \mathrm{~mm})$. During the spring and summer, there was accretion on the lower salt marsh, infilling of the depression at the seaward edge, and some erosion of the mudflat seaward of the salt marsh. The TAC in sediment levels on the intertidal mudflat in 2005 were 16, 23 and $64 \mathrm{~mm}$ for the upper, mid and lower shore posts, respectively (Table 1). A more detailed seasonal cycle of monthly changes in sediment levels at different tidal elevations is presented in Fig. 11. Measurement of seasonal changes in sediment levels at different heights on the shore therefore demonstrated that greatest changes occurred at the seaward edge of the salt marsh. Furthermore, the observed depression in the winter was primarily due to erosion, but this was made more pronounced by some accretion on the upper mudflat immediately seaward of the salt marsh (Fig. 10). The lower shore had the second highest variation in bed level changes despite being exposed to

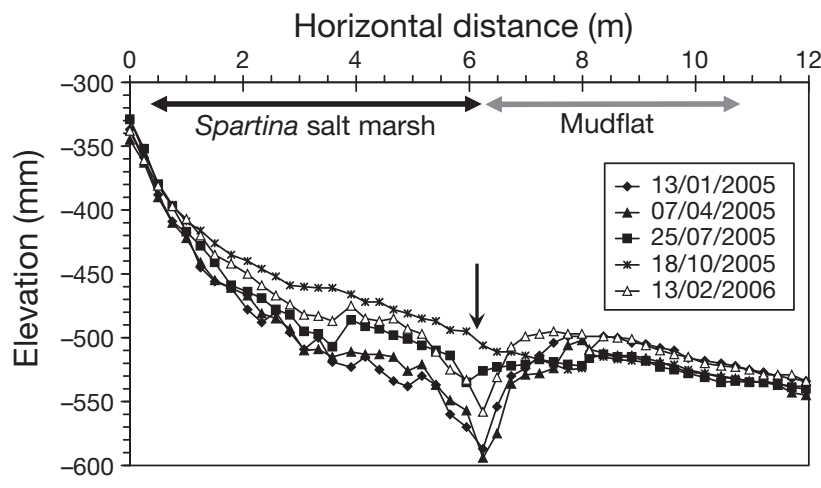

Fig. 10. Seasonal changes in bed elevation on the shore profile covering the seaward edge of the Spartina anglica salt marsh to the upper part of the mudflat. Monthly measurements were made during 2005, but for reasons of clarity only January, April, July, October 2005 and February 2006 are presented here. Bed elevation is relative to fixed posts within the upper salt marsh. Vertical arrow denotes location of acoustic doppler velocimeter for measuring hydrodynamics at seaward edge of the salt marsh. Dates are day/month/year

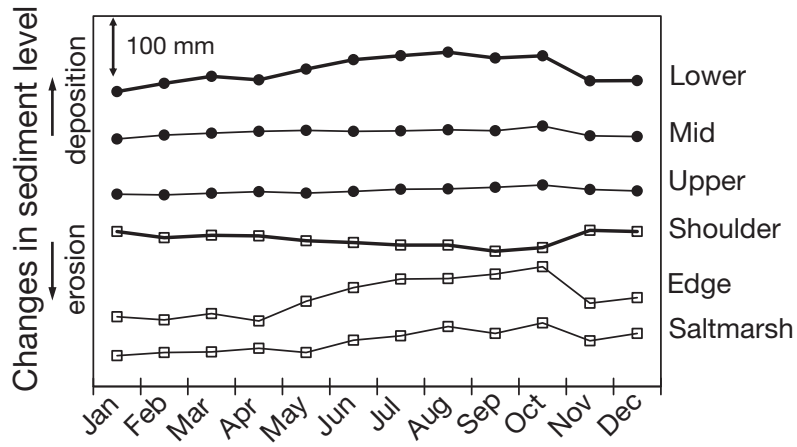

Fig. 11. Relative changes in bed elevation (measured monthly through 2005) at 6 different elevations on the Blaxton shore: salt marsh ( $2 \mathrm{~m}$ from seaward edge), salt marsh seaward edge (depression), shoulder (1.5 m seaward of salt marsh; upper, mid and lower posts on the mudflat (for locations see Figs. 1 \& 2). Vertical line scale $=100 \mathrm{~mm}$

stronger tidal currents $\left(U=0.38 \mathrm{~m} \mathrm{~s}^{-1}\right)$, followed by the salt marsh ( $2 \mathrm{~m}$ from seaward edge), with the mid and upper shore mudflat showing the smallest changes. During the spring and summer accretion period, a surprising but consistent feature within the cordgrass salt marsh was the higher sedimentation in bare areas of mud within the salt marsh, compared to areas with Spartina stems. Fig. 12 illustrates enhanced sediment accretion along a $>6 \mathrm{~m}$ shore-normal strip of mud (ca. $1 \mathrm{~m}$ wide) without Spartina stems. There is a reduction in sediment deposition between the salt marsh stems, compared to areas of bare mud within the salt marsh, and this reflects the enhanced TKE associated with flow through rigid stems that hinder particle settlement.

\section{Relationship between seasonal changes in sediment morphology and physical drivers}

Wind-induced wave activity is a major potential driver of sediment erosion on sediment shores. Fig. 13A

Table 1. Total annual change (TAC) in bed elevation ( $\mathrm{mm}$ ) at different shore heights in 2004 and 2005. Note that fewer measurements were made in 2004, therefore the maximum and minimum sediment levels may not have been recorded, leading to a slight underestimate of TAC

\begin{tabular}{|lcc|}
\hline Location on the shore & $2004(\mathrm{n}=5)$ & $2005(\mathrm{n}=11)$ \\
\hline $\begin{array}{l}\text { Spartina salt marsh (2 m } \\
\quad \text { landward from seaward edge) }\end{array}$ & 21 & 53 \\
$\begin{array}{l}\text { Spartina salt marsh } \\
\quad \text { (seaward edge) }\end{array}$ & 56 & 88 \\
$\begin{array}{l}\text { Upper shore mudflat } \\
\text { Mid shore mudflat }\end{array}$ & 5 & 16 \\
Lower shore mudflat & 14 & 21 \\
\hline
\end{tabular}




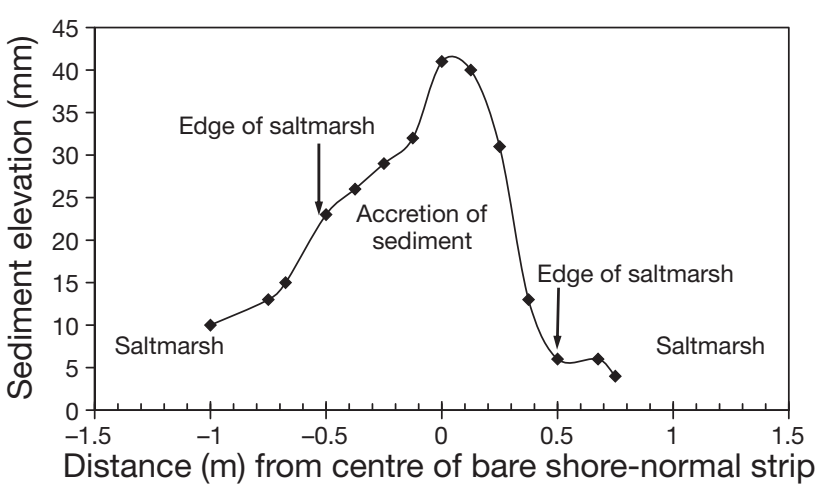

Fig. 12. Sediment level changes across a bare shore area without Spartina anglica stems (representing a rarely used footpath down through the marsh, 17 November 2005). The bare area measured at $\sim 3 \mathrm{~m}$ from front edge extended up through $\sim 6 \mathrm{~m}$ of the lower salt marsh and had higher accretion $(\sim 35 \mathrm{~mm})$ on the bare mud than the salt marsh either side

illustrates the daily mean wind speed over a 2 yr period and Fig. 13B shows the monthly changes in sediment level recorded at the salt marsh seaward edge during 2005, together with less frequent measurements in the latter part of 2004 and the first half of 2006. Sediment erosion was associated with wind events when the daily mean wind speed was $>8 \mathrm{~m} \mathrm{~s}^{-1}$ (Force 5 or more on the Beaufort scale). There was a significant inverse relationship between the number of days with daily mean wind speed $>8 \mathrm{~m} \mathrm{~s}^{-1}$ during the preceding month and the incremental change in sediment level $(\mathrm{p}<$ $0.001, r^{2}=0.61$ ). Sediment erosion occurred during the autumn and winter period when there were storm events in late October and December 2004 and early January 2005, and then in February and April 2005. Note that there was a small accretion in March 2005 due to the lack of any storm events. Gradual sediment accretion then occurred during the spring and summer period from May through to mid October 2005 when the wind speeds were consistently $<8 \mathrm{~m} \mathrm{~s}^{-1}$ and tidal currents at the salt marsh edge induced bed shear stresses well below the $\tau_{\mathrm{e}}$. Storm events in late October and November 2005 resulted in rapid erosion, but, overall, there was less erosion than in the previous winter due to the reduction in the intensity and frequency of storm events (i.e. cumulative wind speed in excess of $8 \mathrm{~m} \mathrm{~s}^{-1}$ was $17.7 \mathrm{~m} \mathrm{~s}^{-1}$ in 2004/5 compared with $3.94 \mathrm{~m} \mathrm{~s}^{-1}$ in 2005/6).

\section{DISCUSSION}

We recorded temporal and spatial changes in nearbed hydrodynamics and sediment bed levels that modify shore-normal profile and intertidal sediment morphology. While there was only sporadic monitoring of

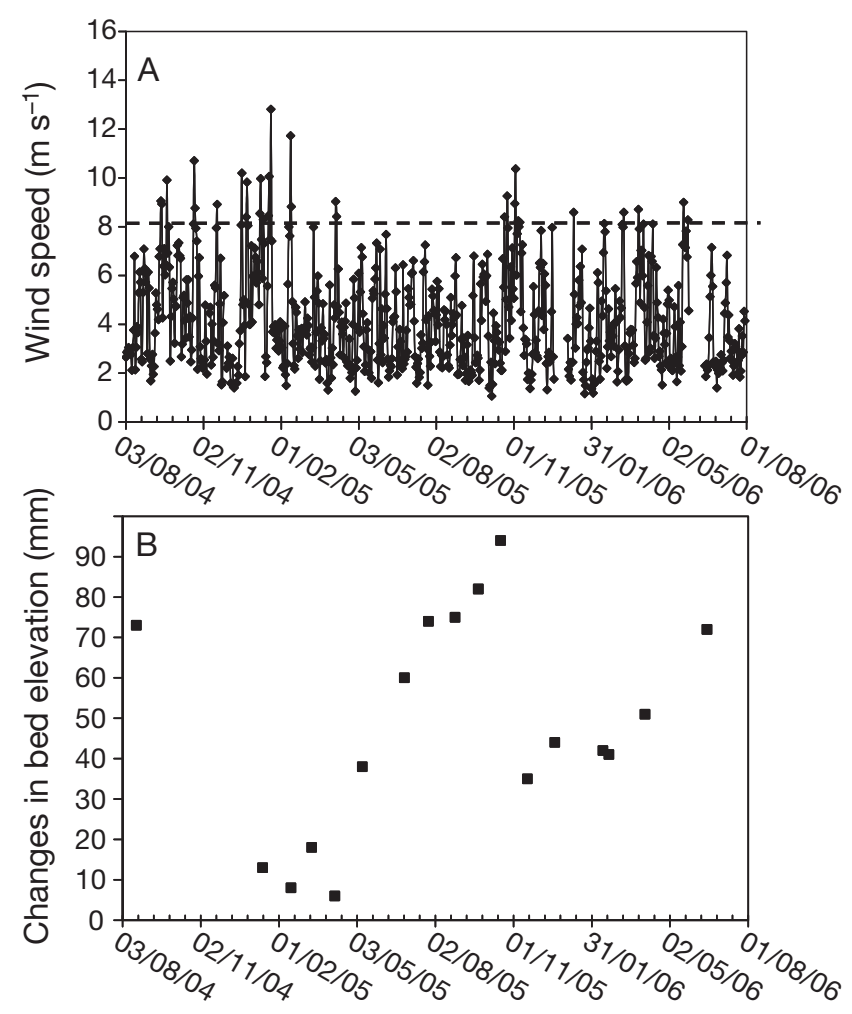

Fig. 13. (A) Mean daily wind speed $\left(\mathrm{m} \mathrm{s}^{-1}\right)$ between August 2004 and August 2006. Dashed line is the threshold mean wind speed of $8 \mathrm{~m} \mathrm{~s}^{-1}$, with points above this representing major wind events. (B) Changes in sediment level at the Spartina anglica salt marsh seaward edge. Note that the sediment erosion and reduction in bed level correspond to wind events, and gradual sediment accretion occurred during spring and summer when mean daily winds speeds were consistently $<8 \mathrm{~m} \mathrm{~s}^{-1}$. Dates are day/month/year

bed levels in 2003, 2004 and 2006, the results were consistent with the detailed monthly records in 2005, indicating that these changes follow a distinct seasonal cycle with sediment erosion during the autumn/winter and accretion during the spring/summer. The greatest changes in sediment levels occurred at the seaward edge of the Spartina anglica salt marsh $($ TAC $=88 \mathrm{~mm})$, with the lower salt marsh $($ TAC $=53 \mathrm{~mm}$ ) and lower mudflat (TAC $=64 \mathrm{~mm}$ ) showing more moderate changes, whilst the upper $(\mathrm{TAC}=16 \mathrm{~mm}$ ) and mid-shore $(\mathrm{TAC}=21 \mathrm{~mm})$ mudflat were least affected.

The spatial and temporal morphological changes on the upper shore were consistent with field and flume measurements of physical-biological interactions between the near-bed flows and cordgrass stems. Under calm conditions, the current speeds and bed shear stresses over smooth mud were typical of smooth turbulent flow (Pope et al. 2006), but windy conditions resulted in a marked increase in $\tau_{0}$, which was above $\tau_{\mathrm{e}}$, at current speeds $>0.06 \mathrm{~m} \mathrm{~s}^{-1}$ (Fig. 9). At the sea- 
ward edge of the salt marsh, Spartina anglica stems were responsible for attenuating mean flow and enhancing TKE in the wakes of stems. Consequently, $\tau_{0}$ was greater than $\tau_{\mathrm{e}}$, with the capacity for sediment resuspension during at least $25 \%$ of the inundation time under calm conditions and $100 \%$ of the time under windy conditions. There was further flow attenuation and energy dissipation by cordgrass stems within the first $2 \mathrm{~m}$ of the salt marsh, but the TKE and $\tau_{0}$ were still elevated sufficiently to induce erosion with $\tau_{0}>\tau_{\mathrm{e}}$ at the beginning of flood tide and at the end of ebb tide during stormy conditions with prevailing wind speeds $>10 \mathrm{~m} \mathrm{~s}^{-1}$. Seasonal morphological changes occurring in the outer salt marsh (i.e. erosion in Fig. 10), suggest that the conditions of elevated TKE (where $\tau_{0}>\tau_{\mathrm{e}}$ ) extend for at least 4 to $5 \mathrm{~m}$ into the salt marsh from the leading edge.

The present field and flume studies have provided evidence for the morphological consequences of stem-flow interactions and the mechanisms involved in enhancing sediment erosion on the upper shore. The enhanced bed shear stress induced by the Spartina stems under windy conditions was far in excess of the $\tau_{\mathrm{e}}$ associated with the Blaxton (Fig. 9) and other Tamar mudflats (Bale et al. 2007). It was also far in excess of the maximum $\tau_{\mathrm{e}}$ recorded using PML annular flumes for bio-stabilised tidal flats dominated by microphytobenthos (i.e. $0.23 \mathrm{~Pa}$, Widdows et al. 2004; note that it is not possible to directly compare these flume-derived values with other estimates of $\tau_{\mathrm{e}}$ based on water jets and other fundamentally different erosion devices, see Widdows et al. 2007). The cordgrass stem-wave interaction in the autumn caused the depression at the front of the salt marsh and this became steadily deeper during the winter, with the lowest sediment levels occurring in April. This depression at the front of the $S$. anglica salt marsh is not restricted to the Blaxton site in the Tavy estuary, but has previously been observed and photographed in the Humber and Westerschelde estuaries (Brown 1998, Bouma et al. 2007). The present study has provided a mechanism to account for the phenomenon.

Immediately seaward of the eroded depression at the edge of the salt marsh, there was a raised shoulder of mud. All field measurements under windy conditions showed that maximum $\tau_{0}$ occurred towards the end of ebb tide when water was draining off the salt marsh as a sheet flow, creating bed shear stresses above the critical erosion threshold. The increase in flow as the water drained from the salt marsh will result in a marked increase in TKE and bed shear stress due to the turbulent wakes induced by stem densities $>400 \mathrm{~m}^{-2}$. This suggests that most of the erosion occurred at the end of the ebb tide, with part of the resuspended sediment then being deposited in front of the salt marsh (as TKE and $\tau_{0}$ declined or decayed downstream of the stems, allowing the shoulder feature to form during the winter months). Unfortunately, the initial and final 15 min of sheet flow and elevated SSC exiting the salt marsh is not measurable with the ADV and OBS when water depth is $<10 \mathrm{~cm}$.

In a plant-flow interaction study by Leonard \& Croft (2006), an abrupt increase in TKE at low flows of $1.2 \mathrm{~cm} \mathrm{~s}^{-1}$ was also recorded at the seaward edge of a Spartina alterniflora salt marsh. This was followed by a logarithmic decline in TKE with distance $50 \%$ within $2 \mathrm{~m}$ under calm conditions, and within $3.2 \mathrm{~m}$ when small wavelets $\left(\mathrm{H}_{\mathrm{s}}<15 \mathrm{~cm}\right)$ were present). However, they (op. cit.) did not measure sediment erodability or actual erosion or deposition, but speculated that this increased turbulence associated with stem-induced wake formation may inhibit deposition and facilitate the transport of sediment further into the marsh. The potential for erosion and transport off the marsh on the ebb tide was not recognised. Leonard \& Croft (2006) recorded higher mean flow velocities and turbulence intensities near the top and bottom of the Spartina alterniflora canopy and this was inversely related to the vertical changes in plant biomass. They suggested that these conditions were less conducive to particle settling at the top and bottom of the canopy. This is consistent with the present study, which recorded higher sediment deposition on bare mud within the salt marsh (Fig. 12), suggesting that the enhanced TKE induced by salt marsh plants causes a hindering of particle settlement compared to bare mud. Neumeier \& Ciavola (2004) also found sedimentation rates within a $S$. maritima salt marsh to be lower than in surrounding areas and, as a result, they surmised that Spartina served to protect sediment from storm erosion rather than enhance sedimentation.

Nyman et al. (2006) highlighted the potential contribution of root growth as well as sedimentation to seasonal changes in sediment levels within a salt marsh. At the Blaxton site, however, the rapid changes associated with the storm event in late October and the parallel temporal changes in sediment levels on the unvegetated mudflat (lower to upper shore) suggest that the bed level changes were primarily due to sedimentation rather than root growth. The percentage volume of the Spartina root/rhizome system $3 \mathrm{~m}$ from the salt marsh edge ( $22 \%$ of total sediment volume) was 4 -fold higher than the volume of root/rhizome system at the salt marsh edge, although the increase in stem density was only 1.5-fold. Consequently, with a proportional increase in root/rhizome volume at higher marsh elevations, belowground vegetative growth is more likely to make a contribution to overall bed level changes at these higher elevations rather than at the seaward edge of the salt marsh, where the major changes occur. 
The assessment of short-term (days) and long-term (months) measurements of hydrodynamic, meteorological and sediment level changes in the present study suggest that there is a threshold mean daily wind speed of $\sim 8 \mathrm{~m} \mathrm{~s}^{-1}$. Above this wind speed, the wavecurrent induced $\tau_{0}$ was significantly greater than the measured $\tau_{\mathrm{e}}$ and there was significant erosion of sediment within $4 \mathrm{~m}$ of the salt marsh edge (e.g. between 18 October and 17 November 2005, $F_{1,25}=180, \mathrm{p}<$ 0.001, ANCOVA). During the autumn and winter period there were several days each month with mean daily wind speeds $>8 \mathrm{~m} \mathrm{~s}^{-1}$ and the wind-wave activity would result in $\tau_{0}>\tau_{\mathrm{e}}$, inducing significant sediment erosion in the outer salt marsh. A threshold wind speed of $8 \mathrm{~m} \mathrm{~s}^{-1}$ is also consistent with previous studies based on sediment resuspension (Smaal \& Haas 1997, French et al. 2000, Houwing 2000).

The results suggest that as few as 2 to $3 \mathrm{~d} \mathrm{mo}$ (February-April 2005) with daily mean wind speeds $>8 \mathrm{~m} \mathrm{~s}^{-1}$ are sufficient to induce some erosion and prevent net accretion at the seaward edge of the salt marsh. The longest period between a wind event $(>8 \mathrm{~m}$ $\mathrm{s}^{-1}$ ) and the measurement of sediment levels on the Blaxton shore was 9 d in 2005 (i.e. winds on 68 November 2005 and monitoring of sediment level on 17 November 2005), indicating that the effect of erosion persists for weeks to months. In fact deposition appears to be a slow process extending over the spring and summer period (6 mo, Fig. 13). A similar slow process of sediment transport from the lower reaches to the mud banks of the upper Tamar estuary (i.e. along an axial transect) during the spring/summer months was recorded by Bale et al. (1985). However, this study (op. cit.) related the seasonal axial cycling of sediment to river flow, with the transport of sediment down the estuary in the autumn/winter. In another study in the Tavy estuary, Uncles \& Stephens (2000) showed elevated SSC in the main channel during the summer and this is the source of sediment supply to the mudflats. Presumably the sediment in the shallow Tavy channel ( $0.5 \mathrm{~m}$ at low tide) is in turn supplied from the main channel of the Tamar estuary throughout the spring and summer months.

Although the same seasonal trends occur at all tidal heights, there was evidence of some slow monthly net accretion (i.e. deposition > erosion) on the lower and mid shores during February and March 2005, despite 3 windy days in February. The mid to lower shore is less vulnerable to wave-induced erosion compared to the upper shore because (1) short period waves ( 1 s), which are a feature of shallow and relatively sheltered estuaries, will not penetrate below $\sim 1 \mathrm{~m}$ and therefore will not affect the bottom during most of the immersion period, and (2) waves act on the shore for longer periods of time around high water when the water level
(<1 m depth) is relatively constant for hours (e.g. immersion time at salt marsh seaward edge $=4.6 \mathrm{~h}$, upper shore $=2.75 \mathrm{~h}$, mid shore $=2.25 \mathrm{~h}$, lower shore $=$ $1.5 \mathrm{~h}$ per tidal cycle). Therefore these features, together with the interaction between Spartina stems and near-bed flow, make the upper shore particularly vulnerable to wind-wave induced erosion. Although the Tavy lower shore may be less exposed to wave action, it is more vulnerable to erosion by stronger tidal currents (and periods of higher riverine flows) with a maximum of $0.38 \mathrm{~m} \mathrm{~s}^{-1}$ at the end of the ebb tide.

Seasonal changes in sediment levels at different tidal elevations are dependent on the sediment supply and the balance between processes of erosion and deposition. On the Blaxton mudflat, deposition continued at a near linear rate from April to October in 2005, as long as there were no storm events, indicating that there was a continuing sediment supply from the Tavy/ Tamar estuary throughout the summer. The fact that the lower, mid and upper shores all accreted during the summer demonstrated that it was not simply a redistribution of sediment on the intertidal shore involving a transfer from the lower to the upper shore. The Blaxton salt marsh (Fig. 10) has a ramp profile with gradually diminishing deposition over a distance of $5 \mathrm{~m}$ with increasing tidal height and relatively constant stem density from 2 to $8 \mathrm{~m}$ from the seaward edge. Water flow through the marsh edge is particularly important during high spring tides in more extensive salt marsh systems (Temmerman et al. 2005). They (op. cit.) showed that an increasing proportion of the water flow and suspended sediment entering the salt marshes was via the marsh edge rather than the creek systems.

The results of the present detailed study of erosion of muddy sediments in a ramp profile salt marsh during wind events are consistent with other estuarine studies. For example, studies in the Westerschelde have related erosion to increases in the tidal prism induced by dredging operations and to westerly winds (Cox et al. 2003). At a macrotidal salt marsh in the Bay of Fundy, van Proosdij et al. $(2000,2006)$ showed that deposition on the marsh (using sediment traps) is primarily related to periods of high SSC and low wave activity, when vegetation height was a small proportion of water depth (i.e. <1). In contrast, coastal studies tend to report significant onshore transport and deposition of coarser sediment within salt marshes in association with storms (Christiansen 1998, Bartholdy et al. 2004). Christiansen (1998) estimated that $27 \%$ of annual sediment deposition on marsh surfaces was contributed by storms, the rest being deposited during normal high spring tides.

Recent studies by Bouma et al. (2007) may provide some insight into apparent discrepancies in the roles of Spartina stems in sediment accretion or erosion. In 
their field experiments, they created low- and highdensity artificial salt marsh beds $(2 \mathrm{~m}$ in diameter) using bamboo canes at a muddy site and at a sandy site. There was a marked erosion of sediment $(\sim 90 \mathrm{~mm})$ within the canes at the muddy site and a tendency for sediment accretion $(\sim 20 \mathrm{~mm})$ at the sandy site. The erosion is consistent with the field observations of turbulence and sediment level changes at the muddy site in the present study. It suggests that changes in topography reflect the balance between erosion and deposition, and at the seaward edge of a Spartina salt marsh this is determined by factors including wind/waves, tidal currents, water depth, stem density (this study), grain size (Bouma et al. 2007) and plant height (van Proosdij et al. 2000, 2006).

The present study confirms that wind-induced wave action is one of the primary drivers of morphological change for an estuarine mudflat and salt marsh, and that the seaward edge of the salt marsh appears to be most vulnerable to erosion. The scale of such changes will be determined by the frequency, direction and intensity of the winds. Analysis of wind speed records in Plymouth, southwest England, indicate that the number of days with a daily mean wind speed of $>8 \mathrm{~m} \mathrm{~s}^{-1}$ was $50 \%$ lower in 2005 (the year studied in detail) than in earlier years $(1999,2000,2002)$. The study period from 2004 to 2006 therefore appears to be one of relatively few storms and probably represent the minimum TAC in bed level likely on the Blaxton mudflat. Consequently, a 2- or 3-fold increase in the frequency and intensity of storms is likely to cause even greater impact on intertidal sediment dynamics and this may lead to marked erosion and retreat of salt marshes. This aspect requires further study in relation to a prediction for increased storminess associated with climate change.

\section{CONCLUSIONS}

We described important interactions between rigid Spartina anglica stems and near-bed hydrodynamics, which can alter intertidal sediment dynamics and sediment morphology. At the seaward edge and for several metres into salt marsh, tidal currents and wind/ waves interact with cordgrass stems enhancing turbulence, TKE and bed shear stress, and thus increase the potential for erosion of muddy sediment. During the autumn and winter, only a few days per month with daily mean wind speeds $>8 \mathrm{~m} \mathrm{~s}^{-1}$ are necessary to cause erosion and prevent significant net sediment accretion on the lower salt marsh ( 6 $\mathrm{m})$. The slow process of accretion occurs during the spring and summer in the Tavy/Tamar estuary, and relies on a steady supply of sediment from the main channel. Contrary to the prevailing viewpoint, spatial and temporal changes in sediment morphology and knowledge of underlying processes indicate that $S$. anglica on the lower salt marsh neither reduces sediment erosion nor enhances net sediment accretion on soft sediment shores. In fact sedimentation rates are higher on patches of bare mud within the salt marsh and immediately seaward of the salt marsh. Therefore cordgrass should not be regarded as a bio-stabliser of muddy sediment. Whilst the initial 10 to $20 \mathrm{~m}$ of salt marsh serve to dissipate wave energy and play a key role in our natural coastal defence, the seaward edges $(\sim 6 \mathrm{~m})$ appear to be particularly susceptible to wind/wave induced erosion as a result of stem-induced increases in TKE and bed shear stress. In the future, the leading edges of salt marshes could be particularly vulnerable to erosion and may recede at an increasing rate in response to predicted increases in the frequency and intensity of storms associated with climate change. Increases in the frequency and intensity of storms will not only increase the degree of fine sediment erosion but also reduce the time available for accretion/recovery between storm events. This represents an important environmental impact in response to both medium and long term changes in climate as well as sea level rise. Climate change models of long term global warming are generally forecasting milder winters and an increase in the intensity and frequency of storms in northwest Europe. This may cause an increase in the erosion and retreat of the seaward edge of salt marshes, as well as a reduction in accretion and the ability of the sediment levels to recover during the summer months. Any processes acting to reduce sediment supply and accretion on salt marshes with a gradual ramp-profile could affect the maintenance and sustainability of these intertidal habitats, and the ability of our natural coastal defences to keep pace with the predicted sea level rise.

Acknowledgements. We thank T. Smyth for providing data from the Plymouth Marine Laboratory (PML) weather station. Meteorological data was also obtained from the University of Plymouth weather station. This study was funded in part by the Natural Environment Research Council Core Research Programme at the Plymouth Marine Laboratory and by Department for Environment, Food and Rural Affairs and the Environment Agency through the Estproc programme (Project No. FD1905).

\section{LITERATURE CITED}

Bale AJ, Morris AW, Howland RJM (1985) Seasonal sediment movement in the Tamar estuary. Oceanol Acta 8:1-6

Bale AJ, Stephens JA, Harris CB (2007) Critical erosion profiles in macro-tidal estuary sediments: implications for the stability of intertidal mud and the slope of mud banks. Cont Shelf Res 27:2303-2312

> Bartholdy J, Christiansen C, Kunzendorf H (2004) Long term variation in backbarrier salt marsh deposition on the Skallingen peninsula — the Danish Wadden Sea. Mar Geol 203: $1-21$ 
Bouma TJ, van Duren LA, Temmerman S, Claverie T, BlancoGarcia A, Ysebaert T, Herman PMJ (2007) Spatial flow and sedimentation patterns within patches of epibenthic structures: combining field, flume and modelling experiments. Cont Shelf Res 27:1020-1045

Brown SL (1998) Sedimentation on a Humber saltmarsh. In: Black KS, Paterson DM, Cramp A (eds) Sedimentary processes in the intertidal zone. Special Publication 139, Geological Society, London, p 69-83

Brown SL, Warman EA, McGrorty S, Yates M and others (1999) Sediment fluxes in intertidal biotopes: BIOTA II. Mar Pollut Bull 37:173-181

Christiansen T (1998) Sediment deposition on a tidal salt marsh. PhD thesis, University of Virginia, Charlottesville, VA

> Christiansen T, Wiberg PL, Milligan TG (2000) Flow and sediment transport on a tidal salt marsh surface. Estuar Coast Shelf Sci 50:315-331

> Cox R, Wadsworth RA, Thomson AG (2003) Long-term changes in salt marsh extent affected by channel deepening in a modified estuary. Cont Shelf Res 23:1833-1846

French CE, French JR, Clifford NJ, Watson CJ (2000) Sedimentation-erosion dynamics of abandoned reclamations: role of waves and tides. Cont Shelf Res 20:1711-1733

Fukuda MK, Lick W (1980) The entrainment of cohesive sediments in freshwater. J Geophys Res 85:2813-2824

> Houwing EJ (2000) Morphodynamic development of intertidal mudflats: consequences for the extension of the pioneer zone. Cont Shelf Res 20:1735-1748

Leonard LA, Croft AL (2006) The effect of standing biomass on flow velocity and turbulence in Spartina alteriflora canopies. Estuar Coast Shelf Sci 69:325-336

Leonard LA, Luther ME (1995) Flow hydrodynamics in tidal marsh canopies. Limnol Oceanogr 40:1474-1484

Leonard LA, Reed DJ (2002) Hydrodynamics and sediment transport and deposition processes in a Juncus roemerianus marsh, west-central Florida. J Coast Res 36:459-469

Leonard LA, Hine AC, Luther ME, Stumpf RP, Wright EE (1995) Sediment transport processes in a west-central Florida open marine marsh tidal creek; the role of tides and extra-tropical storms. Estuar Coast Shelf Sci 41: $225-248$

Möller I (2006) Quantifying saltmarsh vegetation and its effect on wave height dissipation: results from a UK east coast saltmarsh. Estuar Coast Shelf Sci 69:337-351

Möller I, Spencer T, French JR, Leggett DJ, Dixon M (1999) Wave transformation over salt marshes: a field and numerical modelling study from north Norfolk, England. Estuar Coast Shelf Sci 49:411-426

Neumeier U (2005) Quantification of vertical density variations of salt-marsh vegetation. Estuar Coast Shelf Sci 63: 489-496

Neumeier U, Ciavola P (2004) Flow resistance and associated sedimentary processes in a Spartina maritima salt marsh. J Coast Res 20:435-447

- Nyman JA, Walters RJ, Delaune RD, Patrick WH (2006) Marsh vertical accretion via vegetative growth. Estuar Coast Shelf Sci 69:370-380

Pethick JS (1992) Saltmarsh geomorphology. In: Allen JRL, Pye K (eds) Saltmarshes: morphodynamics, conservation and engineering significance. Cambridge University Press, Cambridge, p 41-62

Pethick JS, Leggett D, Husain L (1990) Boundary layers under salt marsh vegetation developed in tidal currents. In: Thornes JB (ed) Vegetation and erosion. John Wiley, Chichester, p 113-123

Pilditch CA, Widdows J, Kuhn NJ, Pope ND, Brinsley MD
(2008) Effect of low tide rainfall on the erodibility of intertidal cohesive sediments. Cont Shelf Res (in press)

Pope ND, Widdows J, Brinsley MD (2006) Estimation of bed shear stress using the turbulent kinetic energy approach - a comparison of annular flume and field data. Cont Shelf Res 26:959-970

> Roast SD, Widdows J, Pope ND, Jones MA (2004) Sedimentbiota interactions: mysid feeding activity enhances water turbidity and sediment erodability. Mar Ecol Prog Ser 281: 145-154

Shi Z, Pethick JS, Pye K (1995) Flow structure in and above the various heights of a salt-marsh canopy - a laboratory flume study. J Coast Res 11:1204-1209

Smaal AC, Haas HA (1997) Seston dynamics and food availability on mussel and cockle beds. Estuar Coast Shelf Sci 45:247-259

Stapleton KR, Huntley DA (1995) Seabed stress determination using the inertial dissipation method and turbulent kinetic energy method. Earth Surf Process Landf 20:807-815

Temmerman S, Govers G, Wartel S, Meire P (2004) Modelling estuarine variation in tidal marsh sedimentation: response to changing sea level and suspended sediment concentrations. Mar Geol 212:1-19

Temmerman S, Bouma TJ, Govers G, Lauwaet D (2005) Flow paths of water and sediment in a tidal marsh: relations with marsh developmental stage and tidal inundation height. Estuaries 28:338-352

Uncles RJ, Stephens JA (2000) Observations of currents, salinity, turbidity and intertidal mudflat characteristics and properties in the Tavy Estuary, UK. Cont Shelf Res 20: 1531-1549

van Proosdij D, Ollerhead J, Davidson-Arnott RGD (2000) Controls on suspended sediment deposition over single tidal cycles in macrotidal salt marsh, Bay of Fundy, Canada. In: Pye K, Allen JRL (eds) Coastal and estuarine environments: sedimentology, geomorphology and geoarchaeology. Special Publication 175, Geological Society, London, p 43-57

van Proosdij D, Davidson-Arnott RGD, Ollerhead J (2006) Controls on spatial patterns of sediment deposition across macro-tidal salt marsh over single tidal cycles. Estuar Coast Shelf Sci 69:64-86

Widdows J, Brinsley MD, Bowley N, Barrett C (1998) A benthic annular flume for in situ measurement of suspension feeding/biodeposition rates and erosion potential of intertidal cohesive sediments. Estuar Coast Shelf Sci 46:27-38

Widdows J, Brinsley MD, Salkeld PN, Lucas CH (2000a) Influence of biota on spatial and temporal variation in sediment erodability and material flux on a tidal flat (Westerschelde, The Netherlands). Mar Ecol Prog Ser 194:23-37

- Widdows J, Brown S, Brinsley MD, Salkeld PN, Elliott M (2000b) Temporal changes in intertidal sediment erodability: influence of biological and climatic factors. Cont Shelf Res 20:1275-1289

> Widdows J, Blauw A, Heip CHR, Herman PMJ and others (2004) Role of physical and biological processes in sediment dynamics of a tidal flat in Westerschelde estuary, SW Netherlands. Mar Ecol Prog Ser 274:41-56

Widdows J, Brinsley MD, Pope ND, Staff FJ, Bolam SG, Somerfield PJ (2006) Changes in biota and sediment erodability following the placement of fine dredged material on upper intertidal shores of estuaries. Mar Ecol Prog Ser 319:27-41

> Widdows J, Friend PL, Bale AJ, Brinsley MD, Pope ND, Thompson CEL (2007) Inter-comparison between five devices for determining erodability of intertidal sediments. Cont Shelf Res 27:1174-1189

Submitted: September 6, 2007; Accepted: February 13, 2008

Proofs received from author(s): June 12, 2008 